\title{
Pre-planular external development in the brooding coral Agaricia humilis
}

\author{
Dirk Petersen $^{1,2, *}$, Godfried W. N. M. Van Moorsel ${ }^{3}$ \\ ${ }^{1}$ Rotterdam Zoo, PO Box 532, 3000 AM Rotterdam, The Netherlands \\ ${ }^{2}$ University of Duisburg-Essen, Institute of Ecology, Department of Hydrobiology, 45117 Essen, Germany \\ ${ }^{3}$ Ecosub, PO Box 126, 3940 AC Doorn, The Netherlands
}

\begin{abstract}
In September 2003, translocation of the scleractinian coral Agaricia humilis on the reef of Curaçao, Netherlands Antilles, was followed by a prodigious release of small floating premature larvae by all colonies $(\mathrm{n}=19)$. Release occurred mainly during the first $3 \mathrm{~d}$ after sampling and peaked with $8.02 \pm 7.60$ (mean $\pm \mathrm{SD}$ ) embryos $\mathrm{cm}^{-2} \mathrm{~d}^{-1}$ on Day 2 . These propagules developed externally into planulae and reached settlement competency about $3 \mathrm{~d}$ after release. During the whole $8 \mathrm{~d}$ monitoring period, the colonies also released normal planula larvae $\left(0.27 \pm 0.39 \mathrm{~cm}^{-2}\right)$, which were able to settle without delay. We assume that premature release occurred as a result of stress connected with the sampling method applied. The obligatory development of at least $3 \mathrm{~d}$ has important consequences for dispersal. This is one of the first reports of successful external development of embryos into planulae in a coral species, known as a brooder, and demonstrates yet another possible mode of reproduction in scleractinian corals.
\end{abstract}

KEY WORDS: Brooder · Embryogenesis $\cdot$ Reproduction $\cdot$ Dispersal $\cdot$ Life history $\cdot$ Planula $\cdot$ Coral

\section{INTRODUCTION}

Scleractinian corals display a great reproductive spectrum: most species reproduce by external fertilization, but many others are known as brooders (Fadlallah 1983, Harrison \& Wallace 1990, Richmond 1997). Also known are unusual patterns such as asexual production of planulae (Stoddart 1983), intra-polypal self-fertilization (Brazeau et al. 1998), bud formation (Boschma 1936, Hoeksema 1989), reversible metamorphosis (Richmond 1985) or polyp bail-out (Sammarco 1982). At least the latter 3 patterns have been shown to be a direct response to environmental stress. The reproductive group of the brooders has been connected so far generally to the release of propagules in the planula stage (Harrison \& Wallace 1990, Richmond 1997). In this study, we show for the first time the extrapolypal development of prematurely released propagules (embryos) in the brooding species Agaricia humilis. The term 'embryo' has been defined by Harrison \& Wallace (1990) as life stages between '...the early development of fertilized eggs up until the stage where the epidermis begins to differentiate and cilia form, at which stage the developing propagule is termed a planula.' Fadlallah (1983) proposed to include all freeliving stages of coral larval ontogeny up to settlement in the term 'planula'. In accordance with Harrison \& Wallace (1990), we define a planula as a ciliated propagule capable of active movement (swimming or crawling).

The Caribbean coral Agaricia humilis is common in shallow reef areas (Van Moorsel 1983, Szmant 1986). A. humilis has adapted to this high-disturbance environment by evolving reproductive characteristics such as early maturity, year-round reproduction and an overall high reproductive output (Van Moorsel 1983).

\section{MATERIALS AND METHODS}

To test an in situ method for collecting larvae of Agaricia humilis for research and aquaculture purposes, 19 colonies (max. diameter $45 \pm 0.7 \mathrm{~mm}$, mean $\pm \mathrm{SD}$ ) were 


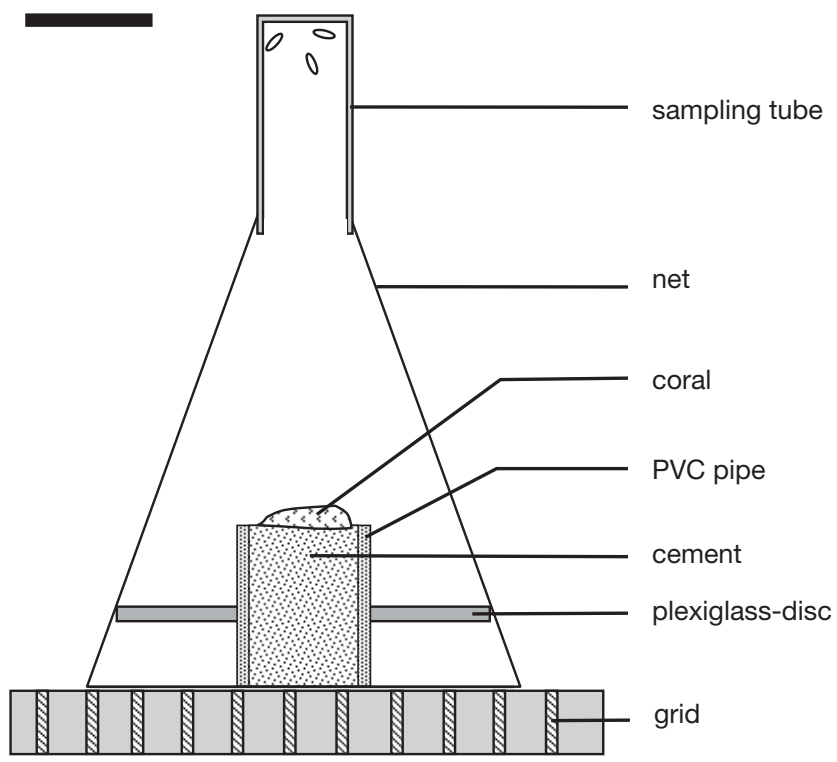

Fig. 1. In situ collection of propagules using cone-shaped $60 \mu \mathrm{m}$ net with a sampling tube (cross-section). Agaricia humilis colonies were mounted on PVC pipes using Portland cement. Scale bar $=5 \mathrm{~cm}$

collected using a hammer and chisel at the fringing reef of Curaçao, Netherlands Antilles. The colonies were brought ashore in separate plastic bags in a transport container and transferred to a $50 \mathrm{l}$ container with ambient seawater. PVC pipes (length $50 \mathrm{~mm}$ ) were filled with Portland cement (Hydraulic Water Stop Cement) and colonies were mounted on them (Fig. 1). The colonies were transferred back to the reef within $30 \mathrm{~min}$ and fixed to a grid located at the collection site at a depth of $7 \mathrm{~m}$; 2 d later, cone-shaped nets (mesh size $60 \mu \mathrm{m}$ ) with a sampling tube at the top were deployed above each colony to collect larvae every morning for the next $8 \mathrm{~d}$. To ensure quantitative sampling, the bottom of each unit was closed with a disc-shaped plexiglass plate (Fig. 1). The number of released propagules per colony was monitored for $8 \mathrm{~d}$. Data were normalized per $\mathrm{cm}^{2}$ colony surface. Surface area was determined from a digital image of each colony, followed by a computer-supported measurement of the surface covered by live tissue (AxioVision 3.1, Carl Zeiss Vision). Propagule sizes are estimates based on photography. Propagules were kept in $100 \mathrm{ml}$ plastic cups in the laboratory; settlement competence was tested with ceramic tiles incubated in aquaria for at least 2 mo prior to the experiments to develop a biofilm including crustose coralline algae.

\section{RESULTS}

In the first $3 \mathrm{~d}$ of the sampling period, all colonies released spheroid propagules (diameter approx. $0.35 \mathrm{~mm}$, volume approx. $0.02 \mathrm{~mm}^{3}$; for calculation see Van Moorsel 1983). These pre-planulae had no outer epidermis, displayed no ciliary activity and drifted passively on the water surface (Fig. 2A). As in most brooding corals, the propagules had acquired zooxanthellae from the parent colonies. Release peaked on the second day of the sampling period with a mean of $8.02 \pm$ 7.60 (mean $\pm \mathrm{SD}$ ) of propagules $\mathrm{cm}^{-2}$ colony surface. A total of $9.29 \pm 7.86$ propagules $\mathrm{cm}^{-2}($ mean $\pm \mathrm{SD}, \mathrm{n}=19$; Fig. 3) was released over $8 \mathrm{~d}$.

Between 36 and $60 \mathrm{~h}$ after release, the embryos developed into small planulae, $\sim 0.5 \mathrm{~mm}$ in length, with a volume similar to that at release (Fig. 2B). Most of these small planulae settled in the following $24 \mathrm{~h}$ near the water surface on the walls of the plastic cups regardless of whether tiles with a biofilm were present or not. No settlement was observed on the tiles, but due to the small size of primary polyps our ability to detect them was limited.

During the $8 \mathrm{~d}$ monitoring period, $65 \%$ of the 19 colonies also released some fully developed planulae (length $\sim 1 \mathrm{~mm}$, total $0.27 \pm 0.39$ larvae $\mathrm{cm}^{-2} 8 \mathrm{~d}^{-1}$; mean $\pm \mathrm{SD}, \mathrm{n}=19$; Fig. 3). More than $90 \%$ of these planulae settled within the first $36 \mathrm{~h}$ after release, exclusively on biologically conditioned tiles.
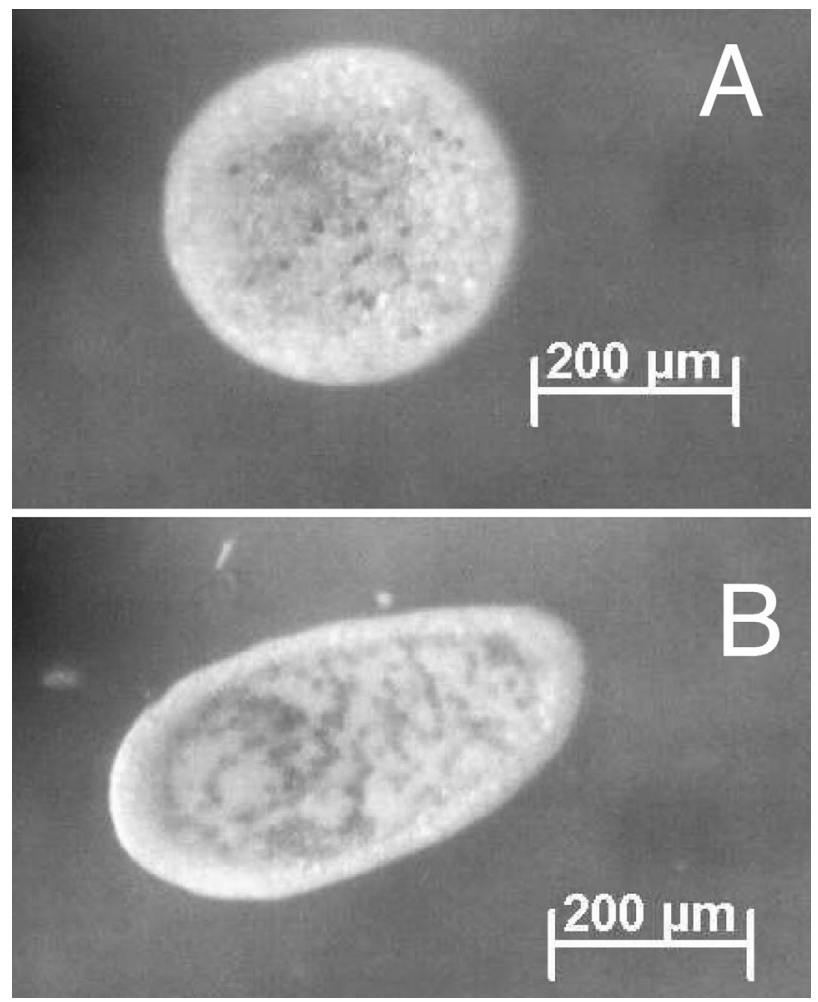

Fig. 2. Agaricia humilis. Morphology of propagules. (A) Preplanular stage with no outer epidermis at time of release; (B) actively swimming planula after approx. $36 \mathrm{~h}$ external development 


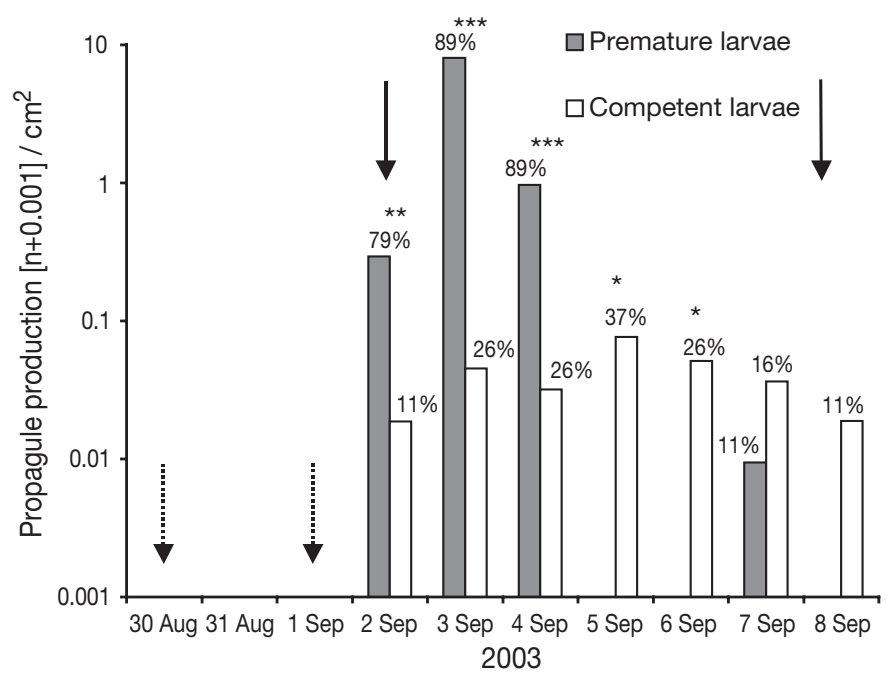

Fig. 3. Agaricia humilis. Release of premature and settlementcompetent planulae $\mathrm{cm}^{-2}$ colony surface after deployment; logarithmic scale. Values above bars: percentage of colonies releasing propagules $(n=19)$. Arrows for 30 August and 1 September 2003 mark day of colony preparation and start of net deployment; other arrows indicate sampling period. Significant differences in fraction of corals releasing premature and settlement-competent planuale are indicated; ${ }^{\star} \mathrm{p}<0.05$; ${ }^{* *} \mathrm{p}<0.01 ;{ }^{* * *} \mathrm{p}<0.001$ (Wilcoxon rank sum test)

\section{DISCUSSION}

We assume that the pre-planulae were in a late embryogenetic stage (Harrison \& Wallace 1990). A comparison of the volume of these propagules with the size range of planulae from 35 Agaricia humilis colonies collected at the reef of Curaçao in 1980 and 1981 (Fig. 4) demonstrates their small size: the average volume of all Curaçao larvae was $0.167 \mathrm{~mm}^{3}$, and the smallest average volume for a colony was $0.041 \mathrm{~mm}^{3}$, almost twice the volume of the premature larvae in this study. In the present study, the volumes of the embryos

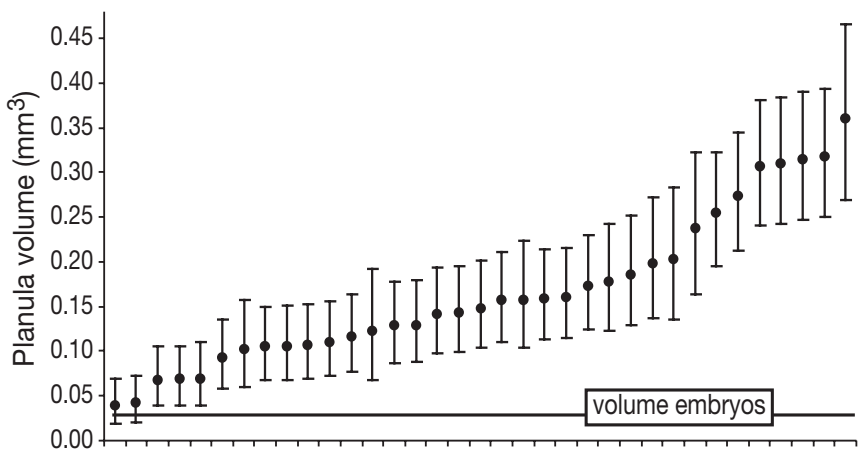

Fig. 4. Agaricia humilis. Volume of 319 planulae from 35 colonies (each with $95 \%$ CI) collected in Curaçao from 1980 to 1981; 95\% CI were calculated after root-transformation of planula volumes. In comparison, mean volume of embryos during present study was $0.022 \mathrm{~mm}^{3}$ and resulting planulae were comparable to planula volumes of Madracis species ( $M$. decactis and M. pharensis: as small as $0.021 \mathrm{~mm}^{3}$ ), which are the smallest known for scleractinian corals (Vermeij et al. 2003).

The number of released pre-planulae was 1 order of magnitude higher than the average of 0.86 planulae $\mathrm{cm}^{-2} \mathrm{wk}^{-1}$ found for Agaricia humilis by Van Moorsel (1983). Our observations further show that coralline algae on the tiles were not ultimately necessary for settlement (some coralline algae are known to induce settlement in A. humilis: Morse et al. 1994, Raimondi \& Morse 2000). The catholic settlement of the small planulae may indicate choice of a less optimal substrate by individuals with a low survival chance. Isomura \& Nishihira (2001) demonstrated a positive relationship between planular size and survival in several brooding species.

We assume that during the hydration process, lime (dissolved as $\mathrm{Ca}^{2+}$ and $\mathrm{CO}_{3}{ }^{2-}$ ) released by Portland cement caused stress to the colonies by increasing the $\mathrm{pH}$ of the surrounding seawater. A reduced water flow around the colony due to the collection nets may have enhanced this effect. Nevertheless, the technique of transplanting corals using Portland cement has been applied previously without any visible negative effects on coral colonies, even when freshly transplanted colonies were kept in a small volume of water for more than 30 h (Petersen et al. 2004). In our study, none of the 19 colonies showed any sign of deterioration during the $8 \mathrm{~d}$ monitoring period; 6 mo later, the same colonies were sampled again over a period of $2 \mathrm{mo}$, at which time they released only normally developed planulae (authors' unpubl. data).

Planula release as a reaction to stress has been previously documented in scleractinians (Edmondson 1929, Loya \& Rinkevich 1979, Fadlallah 1983) and other corals (Henry et al. 2003), but details on larval development have not usually been provided. Only Harii et al. (2001) mentioned the copious release of premature larvae by 1 colony of Alveopora japonica which had been cut in half. These larvae reached settlement competency within $120 \mathrm{~d}$. For the parent colony, disposal of resource-costly propagules may be a reaction to stress.

In addition, our observations demonstrate that in the brooder Agaricia humilis, aborted embryos are able to develop externally into viable planula larvae. External development of these passively floating propagules in the water column results in a settlement delay of at least 2 to $5 \mathrm{~d}$ compared to normal planulae, which are settlement-competent upon release. This has consequences for dispersal. External development of propagules increases the risk of predation through a longer planktonic stage, but may be an adaptation enabling escape from a stress situation and, as such, may represent an attempt to maintain a population by 
avoiding the risk of mortality of undeveloped planulae together with the parent colony. It corroborates the opportunistic life history strategy of A. humilis, which enables this species to persist in an unpredictable environment. This phenomenon of successful external development of embryos in a species known as brooder, adds another mode to the broad spectrum of coral reproduction already documented.

Acknowledgements. We thank the Carmabi Foundation for providing the opportunity of taking microscopic photographs. The Curaçao Sea Aquarium, D. van Bergen and M. Laterveer provided logistic support; A. Cargill, G. Houthoff, K. O'Fallon and E. Reints assisted in the field. M. Hatta and H. Schuhmacher are acknowledged for commenting on the manuscript. D.P. was funded by the scholarship program of the German Federal Environmental Foundation (DBU).

\section{LITERATURE CITED}

Boschma H (1936) Koralen. Voordr Diligentia's Gravenhage 22-33

Brazeau DA, Gleason DF, Morgan ME (1998) Self-fertilization in brooding hermaphroditic Caribbean corals: evidence from molecular markers. J Exp Mar Biol Ecol 231:225-238

Edmondson CH (1929) Growth of Hawaiian corals. Bull Bernice P Bishop Mus 58:1-38

Fadlallah YH (1983) Sexual reproduction, development and larval biology in scleractinian corals. A review. Coral Reefs 2:129-150

Harii S, Omori M, Yamakawa H, Koike Y (2001) Sexual reproduction and larval settlement of the zooxanthellate coral Alveopora japonica Eguchi at high latitudes. Coral Reefs 20:19-23

Harrison PL, Wallace CC (1990) Reproduction, dispersal and recruitment of scleractinian corals. In: Dubinsky Z (ed) Ecosystems of the world, Vol 25, Coral reefs. Elsevier,

Editorial responsibility: Otto Kinne (Editor-in-Chief), Oldendorf/Luhe, Germany
Amsterdam, p 133-207

Henry LA Kenchington ELR, Silvaggio A (2003) Effects of mechanical experimental disturbance on aspects of colony responses, reproduction, and regeneration in the coldwater octocoral Gersemia rubiformis. Can J Zool 81: 1691-1701

Hoeksema BW (1989) Taxonomy, phylogeny and biogeography of mushroom corals (Scleractinia: Fungiidae). Zool Verh 254:1-295

Isomura N, Nishihira M (2001) Size variation and its effect on the lifetime of planulae in three pocilloporid corals. Coral Reefs 20:309-315

Loya Y, Rinkevich B (1979) Abortion effect in corals induced by oil pollution. Mar Ecol Prog Ser 1:77-80

Morse DE, Morse ANC, Raimondi T, Hooker N (1994) Morphogen-based chemical flypaper for Agaricia humilis coral larvae. Biol Bull (Woods Hole) 186:172-181

Petersen D, Laterveer M, Van Bergen D, Kuenen M (2004) Transportation techniques for massive scleractinian corals. Zoo Biol 23:165-176

Raimondi PT, Morse ANC (2000) The consequences of complex larval behaviour in a coral. Ecology 81:3193-3211

Richmond RH (1985) Reversible metamorphosis in coral planulae larvae. Mar Ecol Prog Ser 22:181-185

Richmond RH (1997) Reproduction and recruitment in corals: critical link in the persistence of reefs. In: Birkeland (ed) Life and death of coral reefs. Chapman \& Hall, New York, p 175-197

Sammarco PW (1982) Polyp bail-out: an escape response to environmental stress and a new means of reproduction in corals. Mar Ecol Prog Ser 10:57-65

Stoddart JA (1983) Asexual production of planulae in the coral Pocillopora damicornis. Mar Biol 76:279-284

Szmant AM (1986) Reproductive ecology of Caribbean reef corals. Coral Reefs 5:43-54

Van Moorsel GWNM (1983) Reproductive strategies in two closely related stony corals (Agaricia, Scleractinia). Mar Ecol Prog Ser 13:273-283

Vermeij MJA, Sampayo E, Bröker K, Bak RPM (2003) Variation in planulae release of closely related coral species. Mar Ecol Prog Ser 247:75-84

Submitted: June 18, 2004; Accepted: November 9, 2004

Proofs received from author(s): March 8, 2005 